\title{
論文
}

\section{Application of nonaqueous titration to nitrogen functionality analysis for sedimentary bitumens and a crude oil*}

\author{
Masanobu Yamamoto** and Kazuo Taguchi***
}

(Received December, 21, 1999 ; accepted July 14, 2000)

\begin{abstract}
Nonaqueous titration was used for the analysis of nitrogen functionality in bitumen (solvent extract) from Neogene marine sediments and a crude oil from the Akita Basin, $\mathrm{NE}$ Japan. The nitrogen in bitumen or crude oil was divided into strongly basic nitrogen (SBN; pyridinic-N), weakly basic nitrogen (WBN; mostly amide-N) and nonbasic nitrogen (NBN ; pyrrolic- and nonreactive-N). High SBN/bitumen- $\mathrm{N}$ ratio occurred in the sediment samples that were presumably deposited under high organic flux, suggesting that the abundance ratio relates to paleoproductivity. The SBN/bitumen-N (or SBN/oil-N) ratio was higher in American and Japanese crude oils than in bitumens. The difference is attributed to either their maturity difference or the fractionation during petroleum migration.
\end{abstract}

Key words: organic nitrogen compounds, bitumen, crude oil, nonaqueous titration, depositional environment, petroleum migration, the Onnagawa Formation, the Funakawa Formation, Akita Basin

\section{Introduction}

Nitrogen compounds are well-known constituents of crude oils, with an average content of $0.094 \% \mathrm{~N}$ by weight. The largest amounts are known to occur in California oils, e.g., 0.65 to $0.75 \% \mathrm{~N}$ by weight (Tissot and Welte, 1984). Nitrogen in sedimentary organic matter exists mostly in pyridinic- and pyrrolic-structures (Patience et al., 1992), whilst the nitrogen in living organisms exists mostly as amino acids in proteins. The origin of sedimentary organic nitrogen compounds is still controversial.

A small portion of nitrogen in crude oils and bitumens (solvent extracts) exists as low-

\footnotetext{
* This paper was presented at the 1986 Technical Meeting of the JAPT, June 5, 1986.

** Department of Mineral and Fuel Resources, Geological Survey of Japan.

*** Prof. Kazuo Taguchi passed away March 9, 1996.

Copyright (C) 2000, JAPT
}

molecular-weight heterocyclic compounds such as azaarenes, pyrroles, porphyrins and cyclic amides (Snyder, 1970; Yamamoto et al., 1991). The application of gas chromatographymass spectrometry enables us to study the lowmolecular-weight nitrogen compounds in crude oils and bitumens (e.g., azaarenes by Schmitter et al., 1980, 1983, Bakel and Philp, 1990, Yamamoto et al., 1991; carbazoles by Dorbon et al., 1984, Li et al., 1992 ; alkylnitriles by Evans et al., 1985, Ishiwatari et al., 1992; cyclic amides by Yamamoto et al., 1991 ; azadibenzothiophenes by Grimmer et al., 1983; Yamamoto et al., 1991). High performance liquid chromatography and proton nuclear magnetic resonance spectrometry were applied to the identification of alkylcarbazoles in crude oils (Frolov, 1997; Smirnov and Frolov, 1997). Schmitter et al. (1980) and Dorbon et al. (1984) reported the similar distributional patterns of azaarenes and carbazoles in various 
crude oils of different origin. Bakel and Philp (1990) stated that the distributions of quinolines, benzoquinolines and carbazoles in crude oils depend strongly on the maturity and depositional environment of source rocks, and possibly on migrational fractionation. Their experiment of kerogen pyrolysis indicates the generation of free nitrogen heterocycles from high-molecular-weight organic components such as asphaltenes and kerogens during the oil generation stage. Yamamoto et al. (1991) and Yamamoto (1992) stated that the most important factor in determining the distribution of azaarenes in petroleum is the fractionation caused by geochromatography during petroleum migration.

On the other hand, little is known about the nitrogen functionality in higher-molecularweight fractions such as resins, asphaltenes and kerogen, although nitrogen exists mostly as a moiety of the higher-molecular-weight fractions (Ball et al., 1951). Several methods such as nonaqueous titration (Richter et al., 1952; Okuno et al., 1965 ; Charlesworth, 1986), combined column chromatography, nonaqueous titration and infrared spectrometry (Snyder and Buell, 1965; Snyder, 1970) and X-ray photoelectron spectrometry (XPS) (Patience et al., 1992 ; Wilhelms et al., 1992) have been applied.

Richter et al. (1952) reported that nitrogen compounds in crude oils can be separated into basic and nonbasic compounds using nonaqueous titration with perchloric acid, and demonstrated that the abundance ratio of basic nitrogen to total nitrogen is nearly constant (25\%-30\% by weight) regardless of the source of the crude oils. Okuno et al. (1965) used a modified nonaqueous titration to separate organic nitrogen of crude oils into strongly basic, weakly basic and nonbasic nitrogens, and found a large variation of these three types in ten different American crude oils. Wilhelms et al. (1992) used XPS for the analysis of crude oils and pointed out that the abundance ratio of pyridinic to pyrrolic moieties seems to be independent of source and maturity of the oils.
The XPS investigations also demonstrated that pyrrolic- and pyridinic-N structures are present at very shallow burial depths in the Peru upwelling sediments (Patience et al., 1992).

This paper reports our preliminary results on the distribution of nitrogen types determined by nonaqueous titration in bitumen from Neogene marine sediments of the Onnagawa and Funakawa Formations in Yashima area, Akita Basin, NE Japan. This is the first application of nonaqueous titration to the analysis for the nitrogen moieties of bitumens.

\section{Samples and methods}

Twelve outcrop rock samples were taken from the Onnagawa and Funakawa Formations from middle Miocene to Pliocene ages, occurring in the Yashima area (N39 $11^{\prime}-12$ ', E $\left.140^{\circ} 11^{\prime} 30^{\prime \prime}-12^{\prime}\right)$ in the Akita oil-producing Neogene basin, northern Honshu, Japan (Fig. 1). The maturity of organic matter in the samples ranges from 0.09 to 0.62 of $\beta \beta /$ total hopane ratio, which is equivalent to about $0.3-0.4 \%$ Ro (Yamamoto and Watanabe, 1994). Their sampling location, lithology, biomarker distributions and major elemental compositions are presented in Yamamoto and Watanabe (1994, 1995). The Onnagawa Formation is undoubtedly a petroleum source bed of the Akita oilproducing basin (e.g., Takahashi, 1922). The rock samples were crushed and milled to a particle size of about 200 mesh. A crude oil used for this study was taken from an oil seepage (N39 9'19”, E1407’51') near Sarukura, Chokai Town, Akita Prefecture, Japan.

Bitumen was isolated from powdered rock by extraction with a mixture of benzenemethanol-acetone $(70 / 15 / 15 \mathrm{v} / \mathrm{v} / \mathrm{v})$ by shaking in a stoppered glass bottle at room temperature for 30 hours.

Nonaqueous potentiometric titration was conducted according to the modified method of Richter et al. (1952) and Okuno et al. (1965). An aliquot of bitumen or crude oil was dissolved in $25 \mathrm{~m} l$ of benzene. For the analysis of the strongly basic nitrogen (SBN), $50 \mathrm{~m} l$ of 


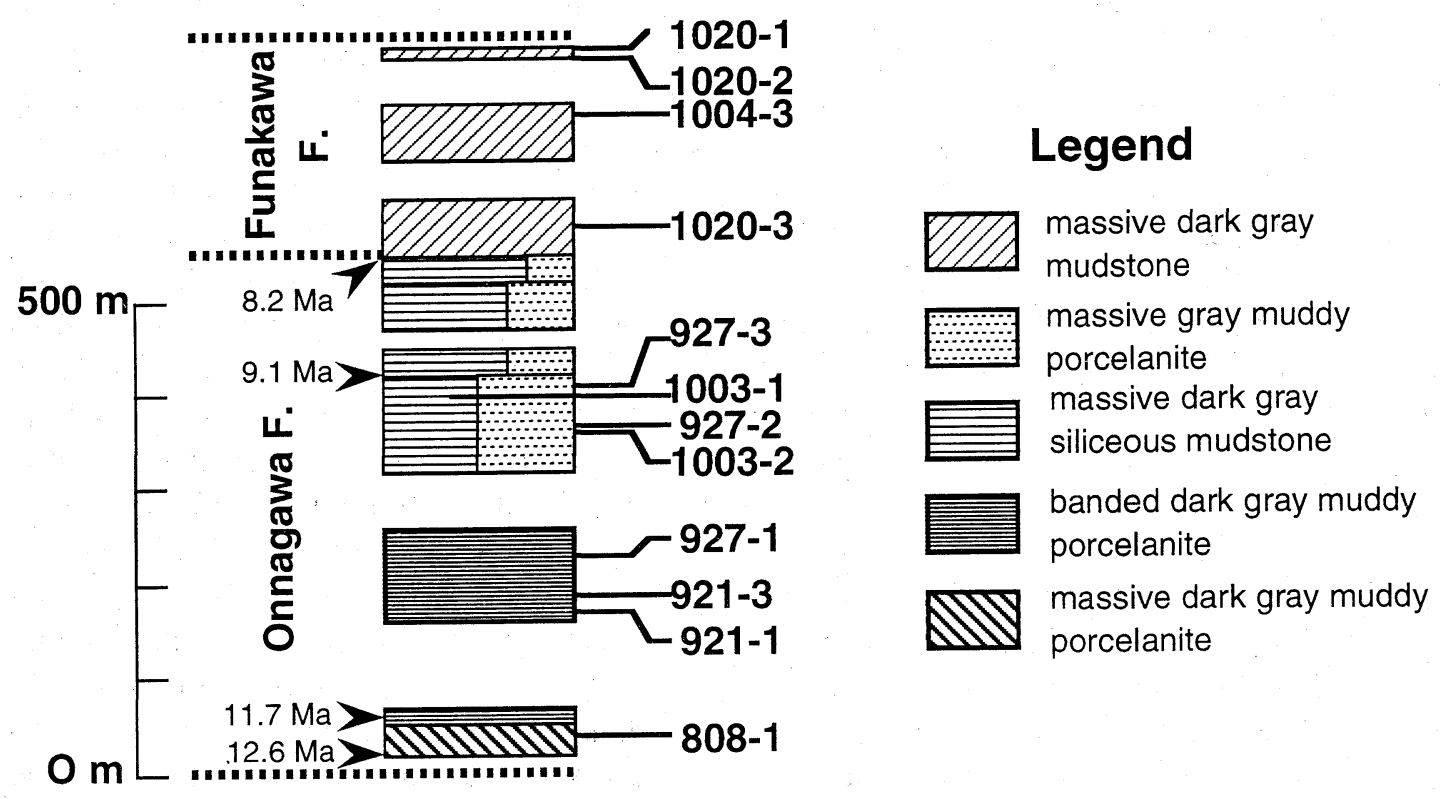

Fig. 1 Schematic stratigraphic column showing sampling points in the Yashima section, NE Japan (Yamamoto and Watanabe, 1994 ; Yamamoto et al., 1999).

acetic acid was added. Acetic anhydride was used instead of acetic acid for the analysis of the weakly basic nitrogen content (WBN). The solution was stirred during titration with $0.1 \mathrm{~mol} / \mathrm{L}$ perchloric acid in dioxane. End point was determined from inflections of the titration curve indicating maximum changes in potential per $\mathrm{m} l$ of titrant (Fig. 2). Calculations include corrections for a blank obtained from a titration curve of the solvent only. One mol of perchloric acid is equivalent to $1 \mathrm{~mol}$ of basic nitrogen atom. Calculations are based on the premise that only nitrogen compounds are being titrated. The SBN content was obtained from the end point (A in Fig. 2) in acetic acid system. The sum of SBN and WBN contents was obtained from the second end point ( $B$ in Fig. 2) in acetic anhydride system. The content of nonbasic nitrogen (NBN) was obtained by subtracting the sum of SBN and WBN contents from the total nitrogen content of bitumen (bitumen=N). In contrast with Okuno et al. (1965), the first break of SBN was hardly recognized in our samples using an acetic anhydride system (Fig. 2). Accordingly,

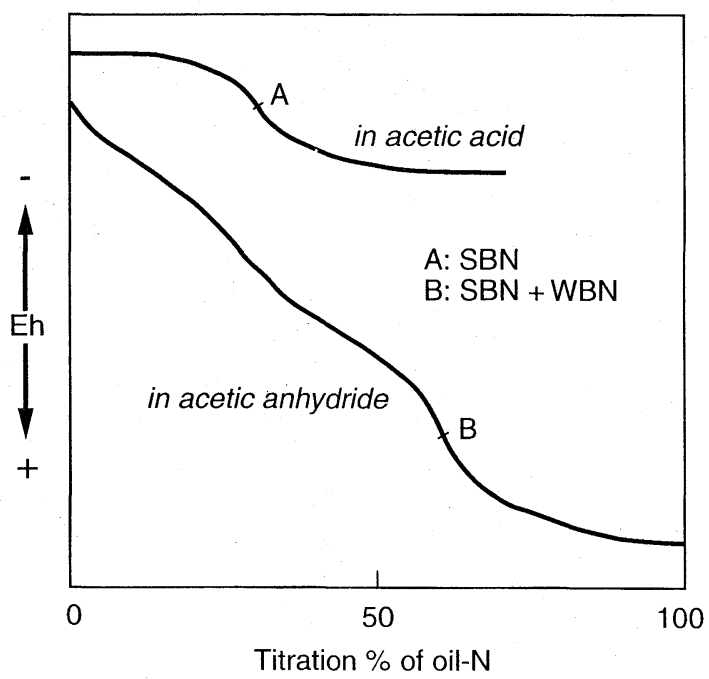

Fig. 2 Perchloric acid titration curve of Sarukura crude oil.

we conducted the titrations both in acetic acid and acetic anhydride systems.

Elemental analyses of carbon, nitrogen and hydrogen contents of bitumen were carried out using a Yanagimoto MT-2 CHN analyzer. The analysis was repeated four times for each sample, and the values were averaged. 


\section{Results and discussion}

\subsection{Nitrogen functionality in bitumens and a crude oil}

Nonaqueous titration determined three types of nitrogen in bitumens and a crude oil according to their basicity (Table 1). Occurrence of nitrogen compounds in crude oils and bitumens (e.g., Richter et al., 1952 ; Okuno et al., 1965 ; Snyder, 1970 ; Yamamoto et al., 1991) suggested us to assign their nitrogen functionality (Fig. 3). The strongly basic nitrogen (SBN) was assigned to pyridinic-N such as alkylpyridines and their benzologues (azaarenes) and partly some substituted pyrroles such as 2, 4-dimethylpyrroles (Richter et al., 1952). Weakly basic nitrogen (WBN) was assigned to amide-N and some pyrrolic-N such as alkylindoles (Okuno et al., 1965). The extremely low concentration of amino acids in the Onnagawa and Funakawa Formations in the Oashizawa section adjacent to the investigated area (Sasaki, 1974) suggests a negligible contribution of peptide-N to WBN. Nonbasic nitrogen (NBN) was assigned to pyrrolic-N such as alkylcarbazoles and their benzologues, possi- bly along with the nonreactive- $\mathrm{N}$ that is the moiety of macromolecular network. Concentrations of free metallo-porphyrins in the Onnagawa and Funakawa Formations of the Yashima section are very low compared to bitumen-N (Taguchi et al., 1969), therefore their contribution to NBN is small.

The contents of SBN, WBN and NBN varied stratigraphically (Fig. 4). The NBN/bitumen$\mathrm{N}$ ratio decreased downward, while $\mathrm{WBN} /$ bitumen-N ratio increased downward. High SBN/ bitumen-N ratios were found in the upper part of the Onnagawa formation and the lower part of the Funakawa Formation. These horizons are characterized by high cholestane/stigmastane ratio, high concentration of 24norcholestane and low organic carbon/total nitrogen ratio, implying that they were deposited under high organic flux (Yamamoto and Watanabe, 1994, 1995 ; Yamamoto et al., 1999). This suggests that the pyridinic-N (SBN) content relates to paleoproductivity. The abundant pyridinic-N structure in high productivity samples may suggest that the organisms abundant in eutrophic water sourced the precursor molecules of pyridinic-N skeleton.

Table 1 Elemental composition and nitrogen functionality of bitumens and a crude oil from the Akita Basin.

\begin{tabular}{|c|c|c|c|c|c|c|c|c|c|c|c|}
\hline \multirow{2}{*}{$\begin{array}{c}\text { Sample } \\
\text { name }\end{array}$} & \multirow{2}{*}{$\begin{array}{l}\% \text { of rock } \\
\text { Bitumen }\end{array}$} & \multicolumn{3}{|c|}{$\%$ of bitumen (oil) } & \multicolumn{3}{|c|}{$\%$ of bitumen (oil) $-\mathrm{N}$} & \multicolumn{4}{|c|}{ p. p. m. of rock } \\
\hline & & $\mathrm{H}$ & $\mathrm{C}$ & $\mathrm{N}$ & SBN & WBN & NBN & bitumen-N & SBN & WBN & NBN \\
\hline $1020-1$ & 0.077 & 11.3 & 73.9 & 1.7 & 13 & 18 & 69 & 13.04 & 1.70 & 2.35 & 9.00 \\
\hline $1020-2$ & 0.086 & 4.9 & 31.3 & 0.7 & 8 & 32 & 60 & 5.76 & 0.46 & 1.84 & 3.46 \\
\hline $1004-3$ & 0.041 & 13.5 & 86.1 & 2.1 & 30 & 18 & 52 & 8.55 & 2.56 & 1.54 & 4.44 \\
\hline $1020-3$ & 0.048 & 12.6 & 82.5 & 1.9 & 23 & 28 & 49 & 9.20 & 2.12 & 2.57 & 4.51 \\
\hline $927-3$ & 0.152 & 12.7 & 81.0 & 2.4 & 17 & 46 & 37 & 36.48 & 6.20 & 16.78 & 13.50 \\
\hline $1003-1$ & 0.159 & 12.2 & 77.1 & 2.5 & 22 & 42 & 36 & 39.75 & 8.75 & 16.70 & 14.31 \\
\hline $927-2$ & 0.197 & 9.5 & 64.7 & 1.9 & 13 & 34 & 53 & 37.43 & 4.87 & 12.73 & 19.84 \\
\hline $1003-2$ & 0.152 & 8.2 & 69.2 & 1.8 & 9 & 40 & 51 & 27.36 & 2.46 & 10.94 & 13.95 \\
\hline $927-1$ & 0.196 & 11.4 & 73.6 & 1.6 & 8 & 50 & 42 & 31.36 & 2.51 & 15.68 & 13.17 \\
\hline $921-3$ & 0.172 & 10.1 & 67.2 & 1.6 & 8 & 48 & 44 & 27.52 & 2.20 & 13.21 & 12.11 \\
\hline $921-1$ & 0.092 & 11.6 & 68.3 & 1.6 & 11 & 58 & 31 & 14.66 & 1.61 & 8.50 & 4.54 \\
\hline $808-1$ & 0.131 & 10.0 & 68.9 & 1.6 & 11 & 62 & 27 & 20.96 & 2.31 & 13.00 & 5.66 \\
\hline \multicolumn{2}{|c|}{ Sarukura oil } & 16.4 & 86.4 & 0.62 & 32 & 36 & 32 & & & & \\
\hline
\end{tabular}

$\mathrm{SBN}=$ strongly basic nitrogen, $\mathrm{WBN}=$ weakly basic nitrogen, $\mathrm{NBN}=$ nonbasic nitrogen. p. p. $\mathrm{m} .=$ parts per million. 
Strongly basic nitrogen (SBN)

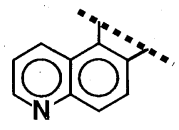

pyridinic-N<smiles>[R]c1cc[nH]c1</smiles>

some pyrroles

\section{Weakly basic nitrogen (WBN)}

<smiles>[R]C12C=CC(NC1)c1ccccc12</smiles>
some indoles

3.2 Differences in nitrogen functionality between crude oils and sedimentary rock bitumens

A SBN-WBN-NBN ternary plot indicates that the relative abundance of SBN is higher in crude oils than in bitumens (Fig. 5). Although a direct comparison between crude oils and sedimentary bitumens of different origins is difficult, their remarkable difference in nitrogen functionality cannot be attributed to the variation of depositional environment only, but to the other geological factors. Previous studies of oil distillates showed that SBN/oil-N ratio of the distillates decreases with increasing boiling temperature range (Fig. 6 ; Richter et al., 1952 ; Okuno et al., 1965 ; Snyder, 1970). This indicates that the SBN is enriched in lower-molecular-weight fractions. Both maturation and petroleum migration decrease average molecular-weight of crude oil constituents by thermal cracking and migrational fraction-

Fig. 3 Nitrogen functionality in bitumens and crude oils.

$\%$ of bitumen-N



Fig. 4 Stratigraphic variations of strongly basic nitrogen (SBN), weakly basic nitrogen (WBN) and nonbasic nitrogen (NBN) contents of bitumen in samples from the Yashima section. 


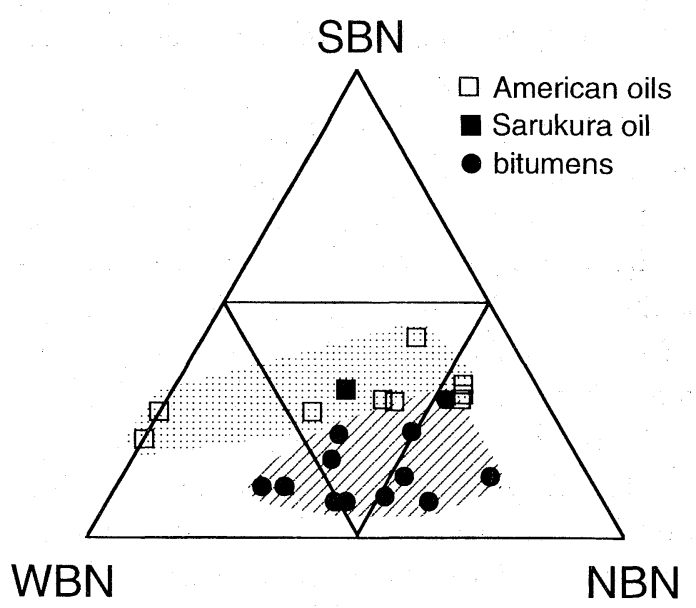

Fig. 5 Ternary plot of strongly basic nitrogen (SBN), weakly basic nitrogen (WBN) and nonbasic nitrogen (NBN) contents of bitumens, a Sarukura crude oil and American crude oils. Data for American crude oils refer to Okuno et al. (1965).

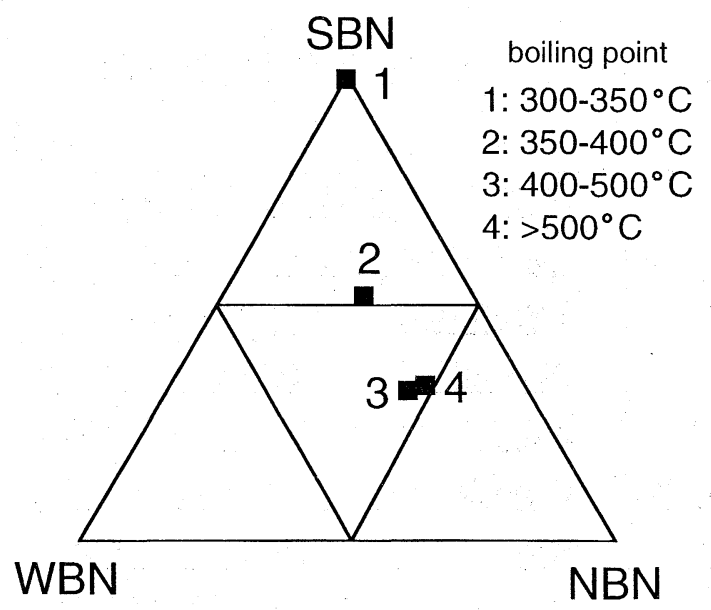

Fig. 6 Ternary plot of strongly basic nitrogen (SBN), weakly basic nitrogen (WBN) and nonbasic nitrogen (NBN) contents of various distillates from a Californian crude oil (Okuno et al., 1965).

ation, respectively.

High $\beta \beta /$ total hopane ratio indicates that the samples from the Yashima section are solely immature (less than 0.4\%Ro) (Yamamoto and Watanabe, 1994). Thus there is a maturity difference between crude oils and the bitumens analyzed in this study. A possible mechanism of increasing basicity with maturation is the ring expansion of nonbasic pyrrolic- to basic pyridinic-structures (Sundberg, 1970). While the previous studies indicated that maturation does not affect basic-N/nonbasic-N (pyridinic-N/pyrrolic-N) ratio of crude oils (Richter et $a l$., 1952 ; Wilhelms et al., 1992), a XPS study for coals demonstrated that pyridinic-N/pyrrolic$\mathrm{N}$ ratio increases with increasing maturity (Burchill and Welch, 1989). The effect of maturity on nitrogen functionality, therefore, cannot be neglected at the present stage and needs to be investigated in more cases.

An alternative explanation is migrational fractionation. Organic nitrogen compounds are highly sensitive to the fractionation of oil composition during primary and secondary migration of petroleum (Charlesworth, 1986; Yamamoto, 1992 ; Li et al., 1992 ; Larter et al., 1996). SBN is richer in crude oils than in bitumens, as demonstrated in the present study. This may suggest that the SBN migrates preferentially during petroleum migration. During the petroleum migration, less polar and lighter compounds migrate preferentially from source rocks to reservoirs, which is regarded as "geochromatography" (Nagy, 1960). Although the SBN (pyridinic-N) has stronger affinity to clay minerals than pyrrolic-N (Chalesworth, 1986), the SBN is enriched in the lowermolecular-weight fraction in crude oils (Okuno et al., 1965 ; Snyder, 1970). If the fractionation of nitrogen functionality is controlled mainly by the molecular-weight of fraction rather than the polarity of functionality, the differences in SBN/bitumen- $\mathrm{N}$ ratio between crude oils and bitumens is attributed to the preferential migration of lower-molecularweight nitrogen compounds during petroleum migration.

Our preliminary result indicates that the difference in SBN/bitumen-N ratio between crude oils and bitumens is attributed to either their maturity difference or migrational fractionation. Further studies are therefore needed to 
evaluate the effects of maturity and migrational fractionation on nitrogen functionality.

\section{Conclusions}

SBN (pyridinic-N) in bitumen was relatively abundant in the sediment samples that were presumably deposited under high organic flux, suggesting that the content relates to paleoproductivity. The relative abundance of SBN (pyridinic-N) was higher in crude oils than in bitumens. Because the difference can be attributed to either their maturity difference or the molecular-weight-controlled fractionation of organic nitrogen molecules during petroleum migration, further studies are needed both on the effects of maturation and petroleum migration.

This preliminary result indicates that nonaqueous titration can be applied to characterizing nitrogen functionality of bitumen. The method will be useful for better understanding the origin, diagenetic changes and migrational fractionation of nitrogen moieties in highermolecular-weight fractions of sedimentary bitumens and crude oils.

\section{Acknowledgements}

The author (M.Y.) thanks Dr. Shigenori Ogihara, University of Tokyo, and Dr. Kiyotaka Sasaki, Tohoku University, for their helpful discussions and experimental assistance.

\section{References}

Bakel, A. J. and Philp, R.P., 1990: The distribution and quantitation of organonitrogen compounds in crude oils and rock pyrolysates. Org. Geochem., 16, 353-367.

Ball, J. S., Whisman, M. L. and Wenger, W. J., 1951 : Nitrogen content of crude petroleums. Ind. Eng. Chem., 43, 2577-2581.

Burchill, P. and Welch, L. S., 1989 : Variation of nitrogen content and functionality with rank for some UK bituminous coals. Fuel, 68, 100-104.

Charlesworth, J. M., 1986 : Interaction of clay minerals with organic nitrogen compounds released by kerogen pyrolysis. Geochim. Cosmochim. Acta, 50, 1431-1435.

Dorbon, M., Schmitter, J. M., Garrigues, I., Ignatiadis,
I., Eward, M., Arpino, P. and Guiochon, G., 1984 : Distribution of carbazole derivatives in petroleum. Org. Geochem., 7, 111-120.

Evans, E. J., Batts, B. D., Cant, N. W. and Smith, J. W., 1985: The origin of nitriles in shale oil. Org. Geochem., 8, 367-374.

Frolov, E. B., 1997 : Liquid chromatography of petroleum carbazoles. Org. Geochem., 26, 43-47.

Grimmer, G., Jacob, J. and Naujack, K. W., 1983: Characterization of $\mathrm{CH}_{2}$-homologous azaarenes in petroleum by capillary gas chromatography and mass spectrometry. Anal. Chem., 55, 2398-2404.

Ishiwatari, R., Sugawara, S. and Machihara, T., 1992 : Long-chain aliphatic nitriles in pyrolysates of young kerogen : implications for the intermediates in petroleum hydrocarbon formation. Geochem. J., 26, 137-146.

Larter, S. R., Bowler, B. F. J., Li, M., Chen, M., Brincat, D., Bennett, B., Noke, K., Donohoe, P., Simmons, D., Kohnen, M., Allan, J., Telnæs, N. and Horstad, I., 1996 : Molecular indicators of secondary oil migration distances. Nature, 383, 593-597.

Li, M., Larter, S. R. and Stoddart, D., 1992 : Liquid chromatographic separation schemes for pyrrole and pyridine nitrogen aromatic heterocycle fractions from crude oils suitable for rapid characterization of geochemical samples. Anal. Chem., 64, 1337-1344.

Nagy, B., 1960 : Review of the chromatographic "plate" theory with reference to fluid flow in rocks and sediments. Geochim. Cosmochim. Acta, 19, 289296.

Okuno, I, Latham, D. R. and Haines, W. E., 1965 : Type analysis of nitrogen in petroleum using nonaqueous potentiometric titration and lithium aluminum hydride reduction. Anal. Chem., 37, 54-57.

Patience, R. L., Baxby, M., Bartle, K. D., Perry, D. L., Rees, A. G. W. and Rowland, S.J., 1992 : The functionality of organic nitrogen in some recent sediments from the Peru upwelling region. Org. Geochem., 18, 161-169.

Richter, F. P., Caesar, P. D., Meisel, S. L. and Offenhauer, R. D., 1952 : Distribution of nitrogen in petroleum according to basicity. Ind. Eng. Chem., 44, 26012605.

Sasaki, K., 1974 : Stratigraphic distribution of amino acid assemblage in the Kusanagi Formation of Oashizawa, Yamagata Prefecture. J. Jap. Assoc. Petrol. Technol., 39, 44-52. (in Japanese with English abstract).

Schmitter, J. M., Vajta, Z. and Arpino, P. J., 1980: Investigation of nitrogen bases from petroleum. In Douglas, A. G. and Maxwell, J. R., ed.: Advances in Organic Geochemistry 1979, 67-76. Pergamon Press. 
Schmitter, J. M., Ignatiadis, I. and Arpino, P. J., 1983 : Distribution of diaromatic nitrogen bases in crude oils. Geochim. Cosmochim. Acta, 47, 1975-1984.

Smirnov, M. B. and Frolov, E. B., 1997: A study of petroleum alkylcarbazoles using ${ }^{1} \mathrm{H}$ NMR spectrometry. Org. Geochem., 26, 33-42.

Snyder, L. R. and Buell, B. E., 1965 : Characterization and routine determination of certain non-basic nitrogen types in high-boiling petroleum distillates by means of linear elution adsorption chromatography. Anal. Chim. Acta, 33, 285-302.

Snyder, L. R., 1970 : Petroleum nitrogen compounds and oxygen compounds. Acc. Chem. Res., 3, 290-299.

Sundberg, R. J., 1970: The chemistry of indoles. In Blomquist, A. J., ed.: Organic Chemistry Vol. 18, 331 -340. Academic Press.

Taguchi, K., Sasaki, K. and Ushijima, N., 1969 : Geochemical significance of porphyrin pigments in the Neogene Tertiary rocks. 1. Yashima Oil Field, Akita Prefecture, Japan. Sci. Rept. Tohoku Univ., Ser. III, 10, 333-348.

Takahashi, J., 1922 : The marine kerogen shales from the oil field of Japan : A contribution to the study of the origin of petroleum. Sci. Rept. Tohoku Univ., Ser. III, 1, 63-156.

Tissot, B. P. and Welte, D. H., 1984 : Petroleum Formation and Occurrence, 2 nd edn. Springer-Verlag.

Wilhelms, A., Patience, R. L., Larter, S. R. and Jorgensen, S., 1992 : Nitrogen functionality distributions in asphaltenes isolated from several oils from different source rock types. Geochim. Cosmochim. Acta, 56, 3745-3750.

Yamamoto, M., Taguchi, K. and Sasaki, K., 1991 : Basic nitrogen compounds in bitumen and crude oils. Chem. Geol., 93, 193-206.

Yamamoto, M., 1992:Fractionation of azaarenes during oil migration. Org. Geochem., 19, 389-402.
Yamamoto, M. and Watanabe, Y., 1994 : Biomarker geochemistry and paleoceanography of Miocene Onnagawa diatomaceous sediments, northern Honshu, Japan. In Iijima, A., Abed, A. M. and Garrison, R. E. ed.: Proc. 29th Int. Geol. Congr. Part C: Siliceous, Phosphatic and Glauconitic Sediments of the Tertiary and Mesozoic, 53-74. VSP.

Yamamoto, M. and Watanabe, Y., 1995 : Molecular geochemical approach to the paleoceanographic assessment of Neogene sediments of Yashima area, Akita Basin, Japan. J. Jap. Assoc. Petrol. Technol., 60, 27-38.

Yamamoto, M., Watanabe, Y. and Watanabe, M., 1999 : Paleoceanographic controls on the deposition of Neogene petroleum source rocks, NE Japan. Bull. Geol. Surv. Japan, 50, 361-376. (in Japanese with English abstract).

$$
\begin{gathered}
\text { 要 旨 } \\
\text { 非水滴定法によるビチュメンおよび } \\
\text { 原油中の窒素官能基のタイプ分析 } \\
\text { 山本正伸・田ロ一雄 }
\end{gathered}
$$

秋田県矢島地域の新第三系女川層・船川層ビチュメン と猿倉原油の窒素官能基を非水滴定法により強塩基性窒 素 (ピリジン態窒素), 弱塩基性窒素（主にアミド態窒 素), 非塩基性窒素（ピロール態窒素と非反応性窒素） に分けて定量した。一次生産性が高かったと考えられる 層準で, 高い強塩基性窒素量が認められた。この含有量 が古一次生産力に関連している可能性が考えられる。ま た, 強塩基性窒素の全窒素に対する割合はビチュメンよ りも原油のほうが高い。この違いの原因として, 熟成度 の違いと石油移動に伴う分別の両者の可能性が考えられ た。 